\title{
CHARACTERISATION OF AUSTROPOTAMOBIUS ITALICUS (FAXON,1914) POPULATIONS IN A CENTRAL SPAIN AREA
}

\author{
R. MARTÍNEZ (1), E. RICO (2) and F. ALONSO (1)*
}

(1) Centro de Investigación Agraria de Albadalejito. Junta de Comunidades de CastillaLa Mancha. Crta. Toledo-Cuenca, km 174. 16194 Cuenca, Spain.

E-Mail: falonso@jccm.es

(2) Departamento Interuniversitario de Ecología. Universidad Autónoma de Madrid. 28049 Madrid, Spain.

E-Mail: eugenio.rico@uam.es

* To whom correspondence should be addressed.

Reçu septembre 2003

Accepté le 22 décembre 2003

Received September, 2003

Accepted December 22, 2003

\begin{abstract}
Crayfish Austropotamobius italicus (Faxon) populations in the province of Cuenca have been periodically monitored with different methodologies, intensity and success since the major outbreaks of crayfish plague which took place during the mid-1980's. During 2000 summer a province-wide sampling program was carried using different sampling strategies. Information about basin characteristics, habitat and crayfish populations was collected. A total of 262 sites within the known or suspected area inhabited by the species were surveyed. A total of 39 populations were found. Nearly $40 \%$ of the populations come from known stocking actions carried by the Environmental Agency for the last twenty years. The populations are found in headwater creeks, are very small, and are usually isolated from the rest of the catchment. Differences between sites with and without $A$. italicus populations were examined. Although its number has not declined sharply during the last decade, several risk factors have been identified.
\end{abstract}

Key-words: crayfish, Austropotamobius italicus, monitoring, habitat.

\section{CARACTÉRISATION DES POPULATIONS D'AUSTROPOTAMOBIUS ITALICUS (FAXON, 1914) DANS UNE AIRE DE L'ESPAGNE CENTRALE}

\section{RÉSUMÉ}

Les populations d'écrevisses Austropotamobius italicus (Faxon) de la province de Cuenca ont été suivies périodiquement à l'aide de différentes méthodologies depuis le milieu des années 1980, période au cours de laquelle est survenue l'épidémie due à la peste. Durant l'été 2000 un vaste programme d'échantillonnage a été réalisé en utilisant différentes stratégies. Des informations portant sur les caractéristiques du réseau hydrographique, de l'habitat et des populations d'écrevisses ont été recueillies. Un total de 262 sites a été prospecté sur l'ensemble de l'aire de répartition de l'espèce. Un total de 39 populations a été trouvé. Pratiquement $40 \%$ des populations proviennent de repeuplements pratiqués par l'agence de l'environnement au cours de ces 20 dernières années. Les populations trouvées en têtes de bassin hydrographique sont de petit taille 
et isolées. Les différences entre sites abritant ou non $A$. italicus sont examinées. Bien que le nombre de populations n'ait pas décliné depuis la dernière décennie, plusieurs facteurs de risque ont été identifiés.

Mots-clés : écrevisses, Austropotamobius italicus, surveillance, habitat.

\section{INTRODUCTION}

Austropotamobius italicus distribution, abundance and habitat range has been substantially reduced in Spain during the last decades. As a result, the species is listed in different regions (sub A. pallipes, see ALONSO et al., 2000 for details), and has also recently become protected in the national legislation (MMA, 2003). Also appears sub A. pallipes in the Red List of Threatened Animals of the International Union for the Conservation of Nature and Natural Resources (IUCN) as a vulnerable species (IUCN, 1996), and in Annexes II and IV of European Community Directives for the Conservation of Natural Habitats and Wild Flora and Fauna (92/43/EEC and 97/62/EU) as an species requiring special conservation measures. Although recent genetic evidence strongly suggests that Austropotamobius italicus was introduced in the lberian Peninsula (GRANDJEAN et al., 2001, GRANDJEAN et al. 2002), there is still concern at management and public levels about this crayfish conservation, due to its heritage value.

Since 1978 a series of epizootic events occurred in Spain and the crayfish plague was found to be the disease responsible for these massive mortalities (CUÉLLAR and COLL, 1983; DIÉGUEZ-URIBEONDO et al., 1997). By 1985, most of the populations had disappeared at Cuenca, which held one of the most important crayfish fisheries in Spain (TORRE and RODRÍGUEZ, 1964), and a first survey to determine the extent of the mortalities and the number of surviving populations was carried that year (LOZANO and MARTÍN, 1988). Since then, province-wide surveys had been undertook in 1986, 1990, 1994 and 1998. The sampling effort and methodology and the degree of specialisation of the involved staff have been variable.

In 2000 a new province-wide survey was planned with a twofold objective: a) Gather more accurate information on $A$. italicus populations including current status, conservation problems, basis for future monitoring programs and detection of adequate areas for stocking and b) developing a methodology for sampling crayfish populations. There was also a special issue to evaluate: recent signal crayfish Pacifastacus leniusculus dispersal in the area. This exotic species was introduced in Spain in 1974 (HABSBURGO-LORENA, 1979), and first stocked in the area in 1986 (LOZANO and MARTíN, 1988). Since then, no new populations were observed until 1994, coincident with the opening of this species fishery in some Spanish rivers (ALONSO et al., 2000). Sites sampled with this particular scope are not analysed in this paper. The results of this work may provide some hints for the species management at the southern end of its current distribution.

\section{MATERIAL AND METHODS}

The study area is located in the province of Cuenca (Central Spain) with the Iberic range at its NE border, attaining a maximum height of $1866 \mathrm{~m}$ (Figures 1, 2). It covers $17140 \mathrm{~km}^{2}$ in a scarcely populated area $\left(11.7\right.$ ind. $\left.\mathrm{km}^{-2}\right)$. The climate is mediterranean with mean annual temperatures from $7.3^{\circ} \mathrm{C}$ to $14.0^{\circ} \mathrm{C}$ and annual rainfall from 400 to over $1100 \mathrm{~mm}$. Most of the province basins belong to three main catchments: river Tajo and river Guadiana, which flow to Atlantic Ocean, and river Júcar, flowing to the Mediterranean Sea. The area inhabited by $A$. italicus is mainly limestone and dolomite country from Cretaceous and Jurassic periods, but there are also substantial Bundtsandstein red sandstone outcrops. 
A total of 262 sites were selected for sampling based on previous surveys, experience of the sampling team and information received from questionnaires sent to Consejería de Agricultura y Medio Ambiente (environmental agency) field staff (Figure 1). All the fieldwork was carried by the same team of three persons during low water period, from mid-June 2000 to the end of September 2000. Different qualitative sampling strategies were selected according to the characteristics of the surveyed stretch: a) active diurnal search for live or dead specimens, moults, signs of crayfish activity, etc., b) nocturnal search with the aid of flashlights, with or without baiting previously the area or c) baited traps. In this last case, four to six $0.4 \mathrm{~m}$ long double-funnelled traps, with $5 \mathrm{~mm}$ mesh, baited with pork or chicken liver, were set in favourable spots (ca. $10 \mathrm{~m}$ apart) in the evening and collected next morning.

Data collected on each site fell within the following six categories: general descriptors, basin descriptors, general and riparian habitat descriptors, instream habitat descriptors crayfish, population data and conservation problems (Table I).

Analysis of frequencies were performed by means of Kruskal-Wallis median test for quantitative data and $\Pi^{2}$ tests for qualitative data. When appropriate, the results obtained were grouped into fewer classes to avoid violating assumptions of the tests or to facilitate interpretation. $p$-values are abbreviated as follows: ns: non-significant $(p>0.05)$; *: $0.01 \leq p<0.05 ;{ }^{* *}$ : $0.001 \leq p<0.01 ;{ }^{* * *}: p<0.001$.

\section{RESULTS}

A. italicus was detected at 38 sites (15.83\%) in two nucleus (Figure 2). One more population was found within the study area after the end of the survey. In the other 224 sites no crayfish were detected. These include 27 sites, which were dry. Pacifastacus leniusculus was found at 2 sites and Procambarus clarkii at 3 sites. We didn't find any

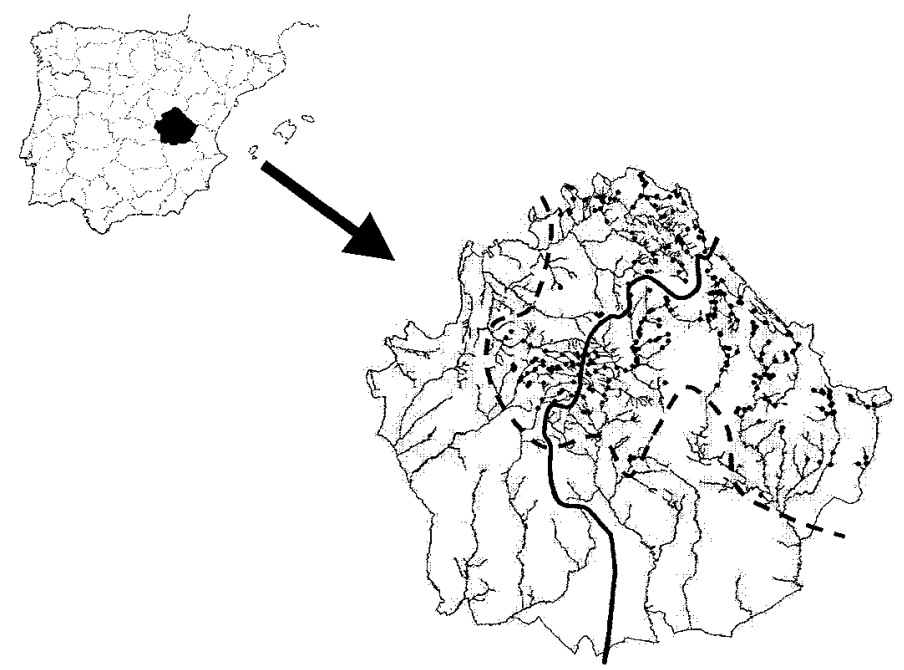

\section{Figure 1}

Study area. The continuous line shows the Mediterranean-Atlantic divide, the dashed line the limits of the study area. Dots represent sampling sites.

\section{Figure 1}

Aire de l'étude. La ligne continue sépare les façades atlantique et méditerranéenne, celle discontinue délimite la zone d'étude. Les points représentent les sites échantillonnés. 


\title{
Table I
}

Variables used in the survey.

\section{Tableau I}

\author{
Variables utilisées dans l'étude.
}

\begin{abstract}
General descriptors
Name of water; Name of sites surveyed; Municipality; Date of visit; Grid data; Sampling team; Height a.s.I. (m); Type of access (4 classes: road, trail, path, without access); Degree of use of access (4 classes); Nearest human settlement (distance in $\mathrm{km}$ measured along main access); Size of settlement (3 classes)
\end{abstract}

\section{Basin descriptors}

Ownership of land (3 classes: private, public or both); Protection level (4 classes according to protection level and value of the area); Land uses (2 groups -modified, unmodified-, each one with several subgroups (slightly modified from SIMMONSON et al., 1994)); Watershed dominating vegetation (10 classes, according to structure and composition); Degree of cover (4 classes with $25 \%$ increases from 0 to 100); Spatial distribution of the cover (3 classes: continuous, discontinuous and in patches)

\section{General and riparian habitat descriptors}

Type of aquatic habitat (4 classes: river, creek, natural pond, artificial pond); Dimensions (average from 3 measures of width and depth per site, surface in ponds); Mean slope ( 3 classes: none or slight, moderate, and strong); intensity of summer drought (3 classes: none, moderate, and strong); channelisation (Yes/No); Isolation from catchment (Yes/ No); Type of barriers (5 classes: cascade, dams, dry stretch, heavy pollution, others); Seasonality (Yes/No); length of stretch with water and length of dried-out stretch (only for isolated reaches); Riparian vegetation formations (6 classes, according to structure and composition); Longitudinal cover (4 classes with $25 \%$ increases from 0 to 100); Vertical stratification (Presence/absence of different strata, i.e.: bushes, epiphytes, etc.); width of buffer strip (over $10 \mathrm{~m} / \mathrm{under} 10 \mathrm{~m}$ )

\section{Instream habitat descriptors}

Macrohabitats (4 classes: pools, riffles, glides and runs); Channel cross-section (8 different geometrical shapes); Bank profile (10 classes of bank profiles); degree of bank alteration (4 degrees of alteration); Substrate size (8 substrate classes, following PLATTS et al., 1983); siltation (Yes/No); consolidation through $\mathrm{CaCO}_{3}$ precipitation (Yes/ No); Existence of refuges (9 different types in the banks and riverbed); Channel shading (4 classes with 25\% increases from 0 to 100); Macrophytes (4 types of macrophytes formations); Macrophyte cover (4 classes with 25\% increases from 0 to 100); Presence of aquatic vertebrate fauna (direct observation or caught in traps, if used)

\section{Population descriptors}

Type of search (4 classes: day, night, baited traps, baits); Time used (h); Length of water with crayfish $(\mathrm{m})$; crayfish species and number detected of each; Size structure (one or several size classes); Moults detected (number and size); Reproductive data (spermatophores attached, cement glands, berried females, juveniles attached); Sanitary state (visible burn spot or porcelain disease symptoms, lack of chelipeds, mortalities, others) Stocking information (if available)

\section{Conservation problems}

American species proximity (3 distance classes); Date of introduction (if known); Fishermen activity intensity (3 classes); Poaching (Suspected/unsuspected); other conservation problems (9 classes, including water use, agriculture, farming, forestry and industrial activities) 
mixed populations, neither of $P$. clarkii and $P$. leniusculus (although there are some examples within the province of Cuenca which are currently under study), nor of any of the American species and $A$. italicus. The number of populations has decreased slightly since 1990 (Figure 3), with an annual rate of loss of $1.52 \%$, but some of the most important populations have disappeared since then. The sharp decrease observed in 1994 is probably due to deficiencies in the survey.

Information collected on a number of the sites without crayfish of found dry was incomplete, or was pooled together. Only data about 138 sites, including all the sites with A. italicus populations, was judged complete enough for analysis.

Sampling effort was mainly devoted to diurnal search (56\%). Night searches and trapping were carried respectively on $13 \%$ and $15 \%$ of the sites. In the other places, more than one sampling strategy was used.

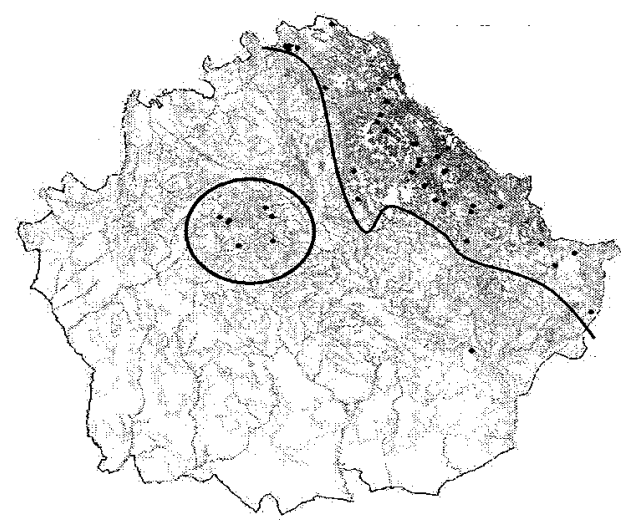

Figure 2

Distribution of $\boldsymbol{A}$. italicus populations in the province of Cuenca.

Figure 2

Distribution des populations d'A. italicus dans la province de Cuenca.

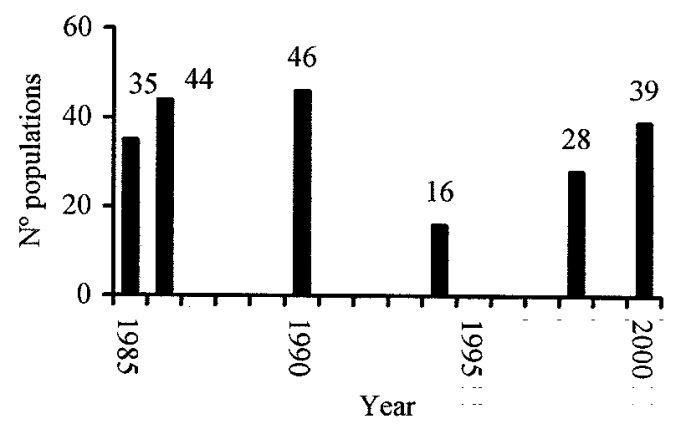

Figure 3

Evolution of the number of $A$. italicus populations in the province of Cuenca (1985-2000).

Figure 3

Évolution du nombre de populations d'A. italicus dans la province de Cuenca (1985-2000). 
Crayfish populations mean distance to the nearest human settlement and to the nearest village were $2.08 \mathrm{~km}$ and $5.03 \mathrm{~km}$ respectively. Mean elevation above sea level was $1134 \mathrm{~m}$, ranging from $870 \mathrm{~m}$ to $1560 \mathrm{~m}$, this being the highest reported value for the species (BOLEA, 1995; ALONSO et al., 2000). It is interesting to point out that very few populations were found within designated areas, and many of them are in private lands (Figure 4). Crayfish inhabit mainly catchments covered with natural pine stands (mostly Pinus nigra salzmanii (Dunal) Franco and, to a lesser extent, Pinus sylvestris L.), with medium to high cover and non-modified land uses in the vicinity of the water.

Most of the populations inhabit fluvial environments (92\%), with moderate or low slope. Non-channelised streams represent a majority (90\%). Influence of summer drought is apparent in $71 \%$ of the cases. In general, populations are isolated from the main fluvial system, usually by the existence of permanent dry stretches. Riparian vegetation is made
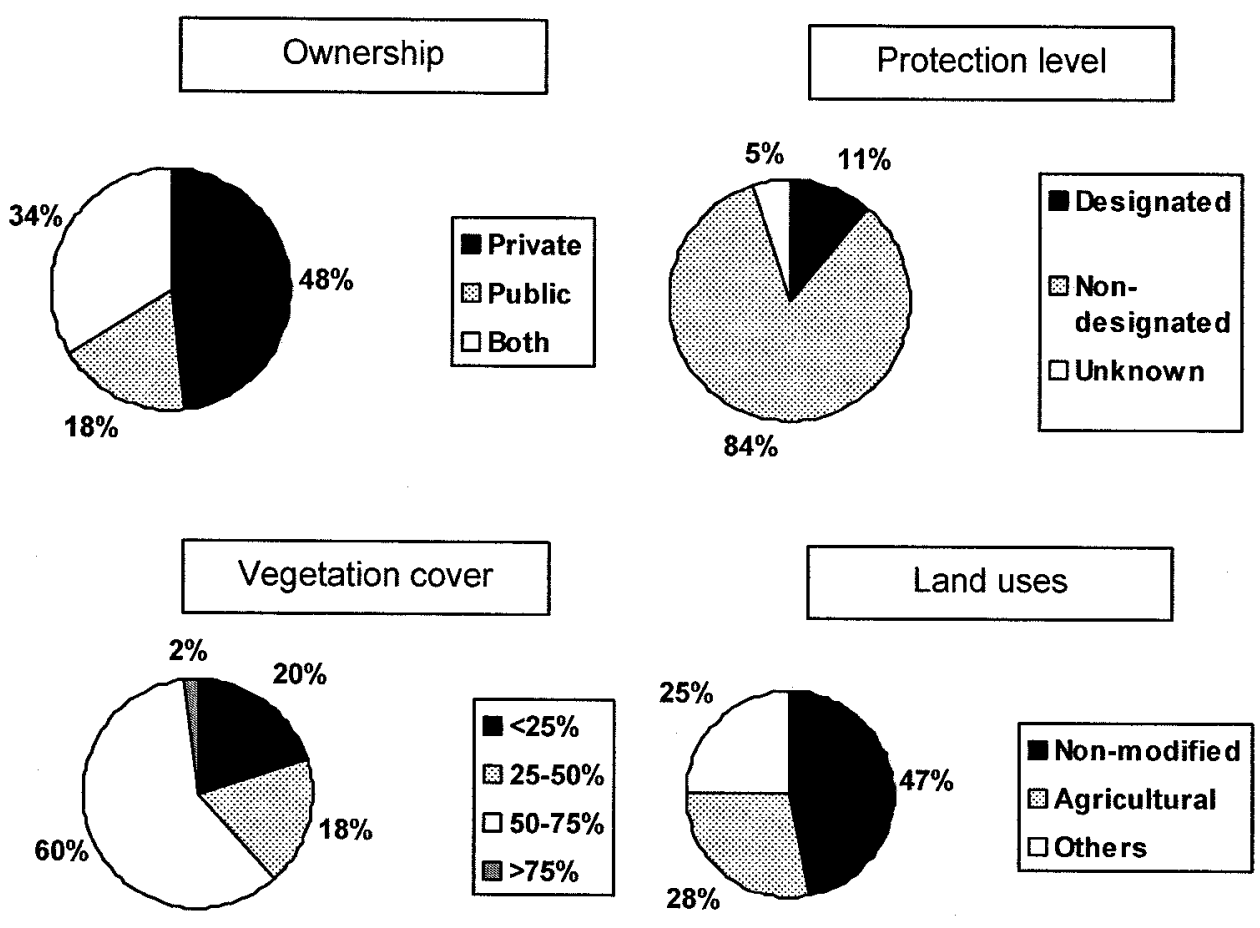

Basin vegetation

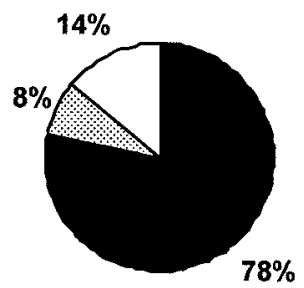

\begin{tabular}{|l|}
\hline Pine forest \\
OShrubs \\
$\square$ Others
\end{tabular}

\section{Figure 4}

Values of selected general basin descriptors at crayfish sites.

\section{Figure 4}

Description générale du bassin versant au niveau des sites à écrevisses. 
up of either tree stands (willows, ashes, elms and poplars) or arbustive cover of willows, thorns and buckets, other kind of covers being scarcer. In most of the waters harbouring crayfish there is a wide buffer strip (>10 m) between the banks and the areas modified by human activity. Riparian vegetation shows frequently some level of vertical stratification, and longitudinal cover is not complete (Figure 5).

The more frequent macrohabitats in $A$. italicus instream habitat are slow flowing waters, either glides (45\%) or pools (34\%), with banks showing some degree of alteration. Fluvial sites holding crayfish were on average $1.55 \mathrm{~m}(0.35-2.55 \mathrm{~m})$ wide and $0.37 \mathrm{~m}(0.12-$ $1.02 \mathrm{~m}$ ) deep. The estimated stretch of water with crayfish had a mean length of $0.87 \mathrm{~km}$ (0.01-1.00 m) (Figure 6).

Populations with either low or high numbers of crayfish were the most frequent. In most cases a well-structured population, showing different size classes, was observed (Figure 6). A rather high number (36\%) of populations were found in places where previous stocking was known to have taken place. Available information on the stocking activities carried in the area between 1989 and 2001 is summarised in Table II. Data prior to 1989 are lacking, and for 1990 are incomplete. The great decline in stocking effort after 1994 is due to the collapse of El Chaparrillo farm production and to changes in management policy. Nearly all the individuals were stocked as summerlings during October, and came from two state-owned facilities, El Chaparrillo and Rillo de Gallo hatcheries, which follow the production scheme outlined by COLL (1986).

Differences between sites holding $A$. italicus populations and sites without the species were examined. Significant differences were found for the following variables: land property, river slope, presence or absence of channelised areas, length of stretch with water, riparian vegetation types and longitudinal cover (Table III).

With regard to conservation problems, $77.8 \%$ of $A$. italicus populations were less than $15 \mathrm{~km}$ apart from American species populations. In $66.7 \%$ of the populations some risk factor was identified, and in $28.6 \%$ of them there was strong evidence of poaching.

Table II

Known crayfish stocking actions in the province of Cuenca during the period 1989-2000.

\section{Tableau II}

Données sur les repeuplements d'écrevisses dans la province de Cuenca pendant la période 1989-2000.

\begin{tabular}{|c|c|}
\hline Year & Total $0^{+}$crayfish stocked $\left(\mathrm{n}^{\circ}\right.$ places) \\
\hline 1989 & $33900(10)$ \\
\hline 1990 & $10200(7)$ \\
\hline 1991 & $25940(17)$ \\
\hline 1992 & $51450(26)$ \\
\hline 1993 & $40000(23)$ \\
\hline 1994 & $106900(32)$ \\
\hline 1998 & $10000(2)$ \\
\hline 2000 & $11075(7)$ \\
\hline
\end{tabular}



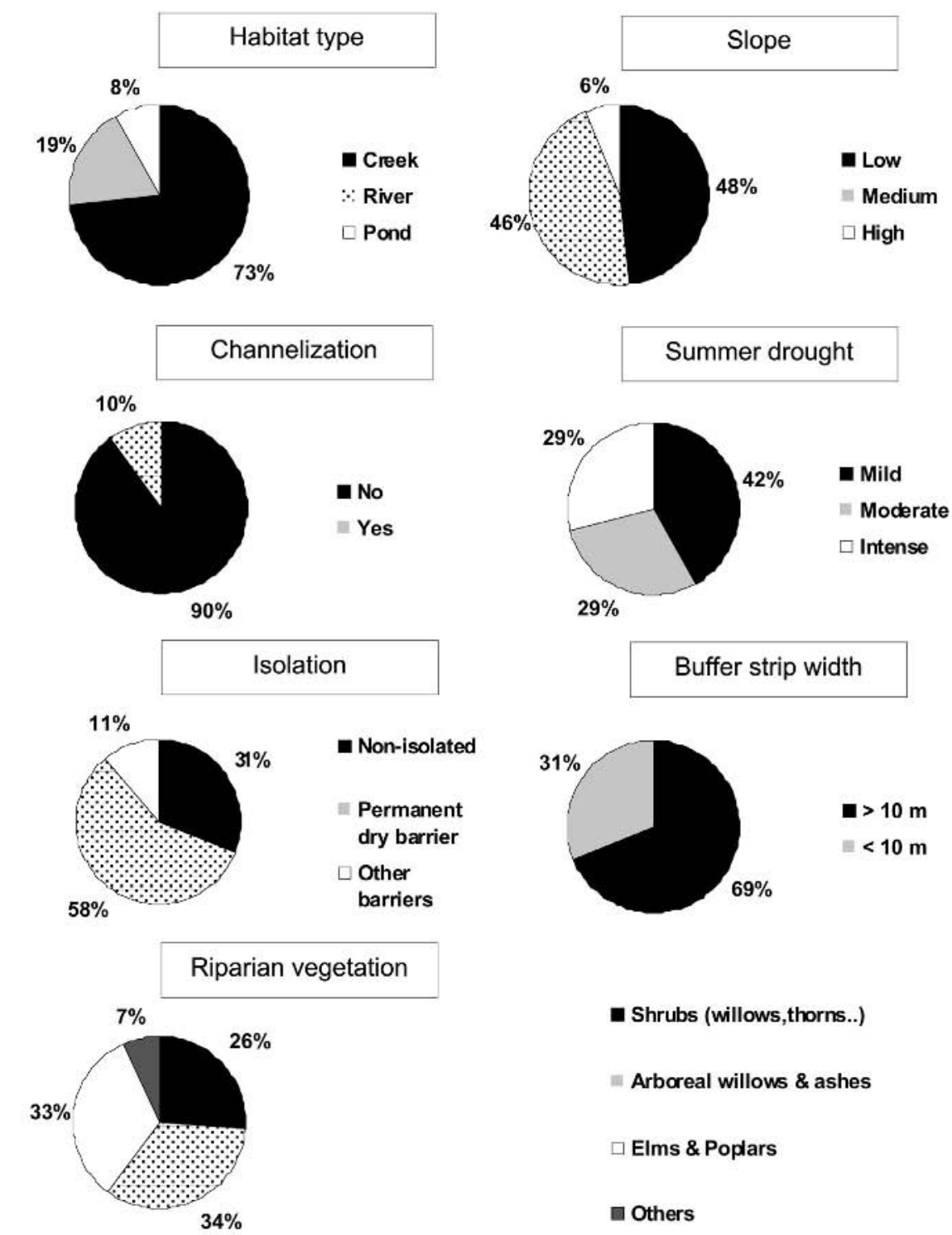

a Shrubs (willows,thorns..)

In Arboreal willows \& ashes

$\square$ Elms \& Poplars

O Others

Riparian vegetation longitudinal cover

Riparian vegetation vertical stratification

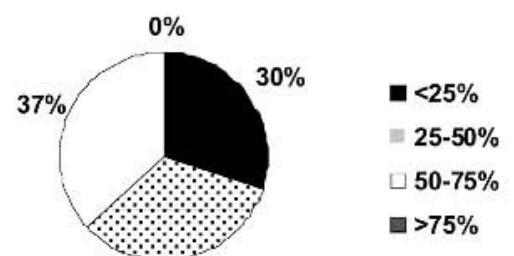

$33 \%$

\section{Figure 5}

Values of selected general and riparian habitat descriptors for crayfish.

\section{Figure 5}

Description générale de l'habitat et de la ripisylve au niveau des sites à écrevisses. 

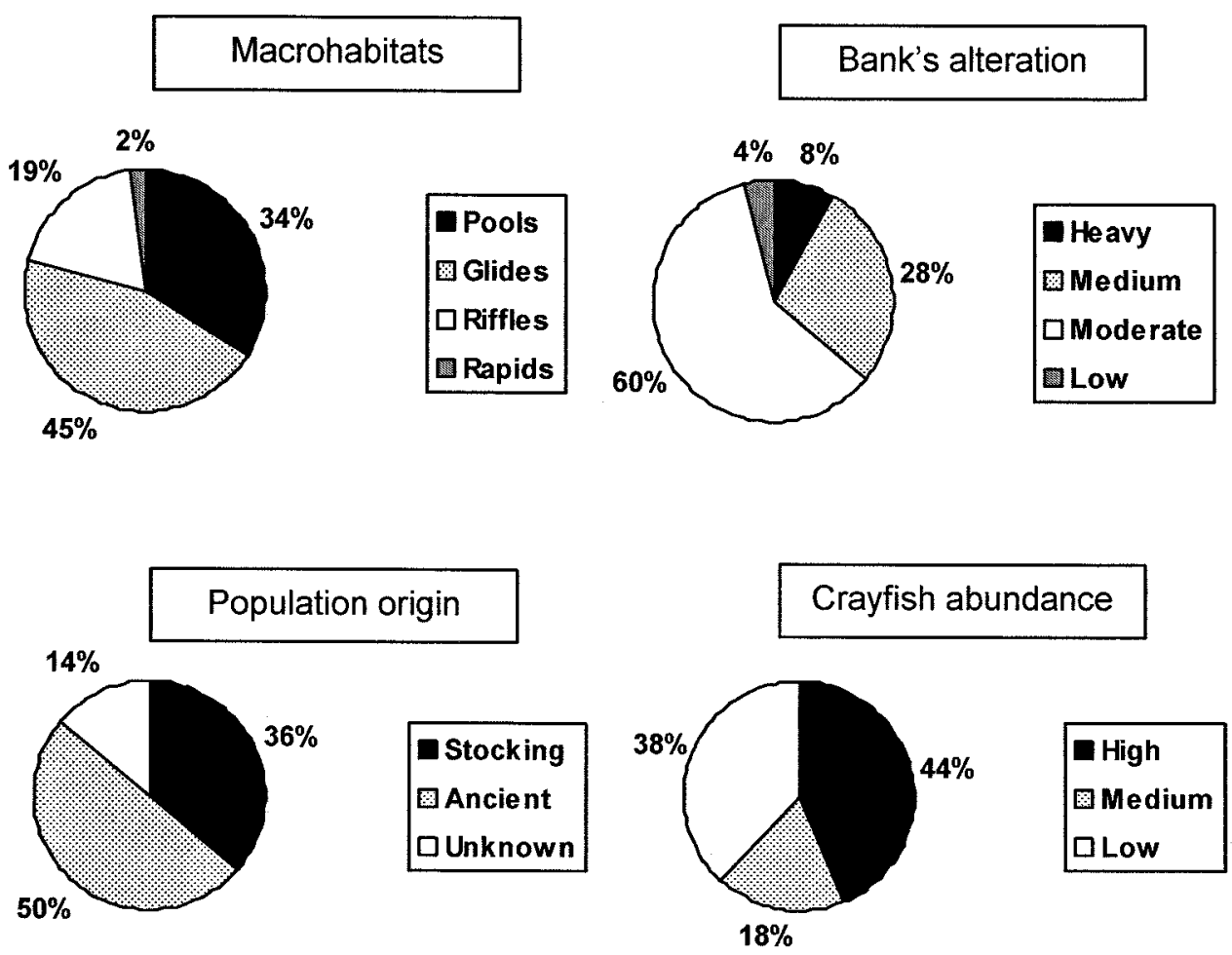

Size structure
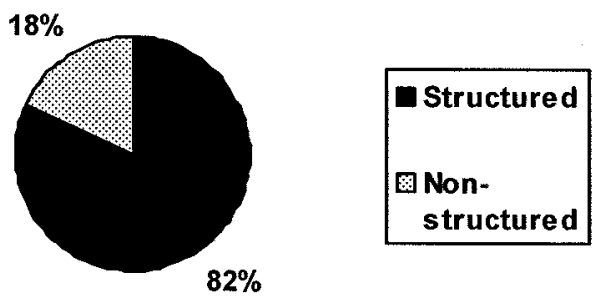

\section{Figure 6}

Values of selected instream habitat and population descriptors.

Figure 6

Caractéristiques de l'habitat à écrevisse et des populations.

\section{DISCUSSION}

The morphological characteristics of the instream and riparian current habitat of A. italicus have been studied in several regions of Spain (see ALONSO et al., 2000 for a review), as well as in other areas (BERNARDO et al., 1997; FÜREDER et al., 2002; SALVIDIO et al., 2002) but there are less works dealing with variables at a basin level, in particular land use, a fact already pointed out by SCHULZ et al. (2002). Crayfish live in Spain in marginal areas of their previous distribution range. Natural pine forests with rather high cover and little land modification are typical of many areas of the lberic range slopes. A common feature for most Spanish populations is that they are found in small creeks, frequently isolated by permanent barriers from the main river system, and that they 
Table III

Comparison of selected variables between sites with and without $A$. italicus populations. In italics, variables that show significant differences. ns: nonsignificant $(p>0.05) ;{ }^{*}: 0.01 \leq p<0.05 ;{ }^{* *}: 0.001 \leq p<0.01 ;{ }^{* * *}: p<0.001$.

Tableau III

Comparaison des variables sélectionnées entre sites avec ou sans populations d'A. italicus. ns : non-significative ( $>0.05)$; * $0.01 \leq p<0.05$; ** $: 0.001 \leq p<0.01$; ${ }^{* \star *}: \mathrm{p}<0.001$.

\begin{tabular}{|l|l|}
\hline Variable & Significance \\
\hline Elevation a.s.I. & $\mathrm{p}=0.1958 \mathrm{~ns}$ \\
\hline Ease of access & $\mathrm{p}=0.5386 \mathrm{~ns}$ \\
\hline Land property & $\mathrm{p}=0.0139^{*}$ (more in public land) \\
\hline Land uses & $\mathrm{p}=0.4015 \mathrm{~ns}$ \\
\hline Watershed vegetation & $\mathrm{p}=0.2268 \mathrm{~ns}$ \\
\hline River width \& depth & $\mathrm{ns} \mathrm{p}=0.4937$ and $\mathrm{p}=0.2809)$ \\
\hline River slope & $\mathrm{p}=0.019^{*}$ (more in steeper reaches) \\
\hline Drought intensity & $\mathrm{p}=0.1541 \mathrm{~ns}$ \\
\hline Channelised stretches & $\mathrm{p}=0.0045^{* *}$ (more in non-channelised) \\
\hline Isolation & $\mathrm{p}=0.7123 \mathrm{~ns}$ \\
\hline Length of water stretch & $\mathrm{p}=0.0019^{* *}$ (more in shorter stretches) \\
\hline Length dry stretch & $\mathrm{p}=0.4690 \mathrm{~ns}$ \\
\hline Riparian vegetation & $\mathrm{p}=0.0001^{* *}$ (more in tree stands) \\
\hline Vertical stratification & $\mathrm{p}=0.9850 \mathrm{~ns}$ \\
\hline Longitudinal cover & $\mathrm{p}=0.0420^{*}$ (more with $<50 \%$ cover) \\
\hline Buffer strip width & $\mathrm{p}=0.6726 \mathrm{~ns}$ \\
\hline Macrohabitats & $\mathrm{p}=0.6216 \mathrm{~ns}$ \\
\hline Substrate concretion & $\mathrm{p}=0.8042 \mathrm{~ns}$ \\
\hline Shade & $\mathrm{p}=0.4522 \mathrm{~ns}$ \\
\hline Macrophyte cover & $\mathrm{p}=0.1972 \mathrm{~ns}$ \\
\hline Presence of fish & $\mathrm{p}=0.3585 \mathrm{~ns}$ \\
\hline & \\
\hline
\end{tabular}

occupy small areas (GAUDIOSO et al., 1987; ALDABE et al., 1991; CARRAL et al., 1993; BOLEA, 1995; GIL, 1999). For example, GARCÍA-ARBERAS and RALLO (2000) found that the species lived in small rivers located upstream, with average width of $1.6 \pm 0.6 \mathrm{~m}$, depth under $0.20 \mathrm{~m}$ and an average slope of $8.8 \pm 4.8 \%$, while BERNARDO et al. (1997) report slightly larger widths $(1.5-7 \mathrm{~m})$ and depths $(0.17-0.5 \mathrm{~m})$. The results of our study support these observations. As opposed to the situation found in Tyrol by FÜREDER et al. (2002) or Germany (TROSCHEL and DEHUS, 1993), where crayfish seem to prefer the lowlands, Spanish populations thrive in the mountains, with the exception of the highest areas. This can also have influence in crayfish being found in less polluted environments, misleading about its water quality indicator value. Isolation can be considered an additional problem in areas where intense drought can lead to total desiccation of the waterbed, with 
no possibility of colonisation as there are no downstream populations. Although the proportion of protected populations is likely to increase in the coming years, this remains a difficult conservation issue to address, as many of them are very small and are located well outside other conservation areas.

Riparian vegetation is a good indicator of availability of habitats in fluvial ecosystems (FÜREDER et al., 2002), and provides elements such as shade and refuge that can be very important in small Mediterranean creeks during the summer drought. These authors showed a relation between changes in land use which damaged or destroyed riparian vegetation and the decline of crayfish populations in South Tyrol. Our results show that the existence of a wide buffer strip or a well-preserved riparian cover is frequent in areas holding crayfish.

One of the major gaps of this survey is the lack of physico-chemical data. ALONSO (2001) studied three populations among those included in this work and found mean annual temperatures ranging from $8.82^{\circ} \mathrm{C}$ to $11.40{ }^{\circ} \mathrm{C}$, with absolute extreme values of $0.6{ }^{\circ} \mathrm{C}$ and $24.0^{\circ} \mathrm{C}$, and a maximum daily range of $10.5{ }^{\circ} \mathrm{C}$. The populations studied by ALONSO (2001) in this area lived in waters with mean conductivity between 457 and $1638 \mu$ S.cm ${ }^{-1}$, higher than those reported by GARCÍA-ARBERAS and RALLO (2000) and BERNARDO et al. (1997) in Portugal. On the other side, TROSCHEL and DEHUS (1993) and TROSCHEL (1997) report that crayfish presence was no dependent on water chemistry.

TEMIÑO and SÁEZ-ROYUELA (1998) did not find remarkable differences in some morphological and physico-chemical variables between rivers harbouring crayfish populations and those in which the species had recently disappeared in the province of Burgos (northern Spain). This is in accordance with most of our data, and suggests that the current distribution of $A$. italicus in these areas is mostly shaped by the past events of crayfish plague. Some of the differences we found between places with and without $A$. italicus could be expected as they are related to better habitat conservation. For example, public forests management tends to be more conservation minded than private ones, and higher slopes are associated with mountain areas where general conservation state is better. The opposite can be said of channelisation works, which are known to have destroyed a number of small creeks harbouring crayfish. On the other hand, we cannot explain the differences found in the length of the stretch with water, with crayfish occupying smaller (more drought prone) stretches. It should be stressed that the comparison was carried between sites in which crayfish presence could be expected during the survey, and thus it is biased towards habitats where populations were living until recently, rather than representing a complete analysis on habitat selection by crayfish.

Diurnal searches are not only effective for detecting crayfish in most situations, but also save time by allowing habitat data collection in the same visit, and increasing the security of the team, especially in unknown areas. On the other hand, it may be difficult to compare crayfish data obtained in diurnal and nocturnal searches. We have found difficulties with some qualitative variables in categories description. It also seems necessary to improve the methodology for deciding where variables should be measured within a site. Also, the need to calibrate survey methodology between groups seems to arise if data are to be compared along the species distribution area.

Our results suggest that most populations in the area are at risk. Although most of the already known conservation problems are present, one emerging problem is the actual dispersal of signal crayfish in the area. RALLO and GARCÍA-ARBERAS (2002) mentioned that $A$. italicus and $P$. leniusculus distribution could overlap as they can use the same habitat. Although vicinity or sympatry frequently ends with the disappearance of Austropotamobius species (HOLDICH et al., 1995), mixed populations of $A$. pallipes and $P$. leniusculus have been previously reported in England (HOLDICH and DOMANIEWSKI, 1995), where its distribution now overlaps in many parts (HOLDICH and ROGERS, 1997). 
We didn't detect any mixed populations of $A$. italicus and any of the American species, but during 2001 a mixed $A$. italicus $-P$. leniusculus population was found at a nearby river Ebrón (URBANO, J. pers.com.), being so far the first record for the species. Stocking success as a management tool for increasing the number of populations have already been stated (HOLDICH and ROGERS, 1997; SCHULZ et al., 2002), and its positive role in the conservation of Spanish populations was pointed out by ALONSO et al. (2000) and confirmed in this work.

\section{ACKNOWLEDGEMENTS}

The authors wish to thank Luis SÁNCHEZ for his help in field sampling. Support from Consejería de Agricultura y Medio Ambiente staff at Cuenca and Toledo is acknowledged. An anonymous reviewer helped with the French text. Financial support came from Servicio de Medio Ambiente Natural at Cuenca, Servicio de Investigación Agraria de Castilla-La Mancha and Instituto Nacional de Investigación y Tecnología Agraria y Alimentaria (INIA) (Projects n ${ }^{\circ}$ SC-96-005/PT-35-RN and SIA 01-189-RN-39). R. MARTíNEZ is supported by a grant from Servicio de Investigación Agraria de Castilla-La Mancha.

\section{REFERENCES}

ALDABE J., ESQUISABEL J.I., FERNÁNDEZ M. J., IRURZUN J.C., MENDÍA F., RUEDA A., YOLDI B., 1991. Estudio de distribucion y abundancia de las especies de cangrejos presentes en los rios navarros. Internal report of the Servicio de Medio Ambiente del Gobierno de Navarra, Negociado de Gestión Cinegética y Piscícola. (In Spanish).

ALONSO F., 2001. Efficiency of electrofishing as a sampling method for freshwater crayfish populations in small creeks. Limnetica, 20(1), 59-72.

ALONSO F., TEMIÑO C., DIÉGUEZ-URIBEONDO J., 2000. Status of the white-clawed crayfish, Austropotamobius pallipes (Lereboullet, 1858), in Spain: Distribution and legislation. Bull. Fr. Pêche Piscic., 356, 31-54.

BERNARDO J. M., ILHEU M., COSTA A.M., 1997. Distribution, population structure and conservation of Austropotamobius pallipes in Portugal. Bull. Fr. Pêche Piscic., 347, 617-624.

BOLEA L., 1995. El cangrejo de río común en Aragón. Diputación General de Aragón. Zaragoza. 64 p. (In Spanish).

CARRAL J.M., CELADA J., GONZALEZ J., SAEZ-ROYUELA M., GAUDIOSO V.R., FERNÁNDEZ R., LÓPEZ-BAISSON C., 1993. Wild freshwater crayfish populations in Spain. Freshwater Crayfish, 9,158-162.

COLL M., 1986. Cultivo del cangrejo autóctono. In GONZALEZ TAPIA J. (Ed.), Jornadas de Estudio del Cangrejo de Río, 122-131. Gobierno Vasco. Departamento de Agricultura y Pesca, Vitoria (In Spanish).

CUÉLLAR L., COLL M., 1983. Epizootiology of the crayfish plague (Aphanomycosis) in Spain. Freshwater Crayfish, 5, 545-547.

DIÉGUEZ-URIBEONDO J., TEMIÑO C., MÚZQUIZ J.L., 1997. The crayfish plague fungus in Spain. Bull. Fr. Pêche Piscic., 347, 753-763.

FÜREDER L., OBERKOFLER B., HANEL R., MACHINO Y., 2002. Freshwater crayfish in South Tyrol (Italy): distribution and protection measures of endangered Austropotamobius pallipes. Bull. Fr. Pêche Piscic., 367, 651-662. 
GARCÍA-ARBERAS L., RALLO A., 2000. Survival of natural populations of Austropotamobius pallipes in rivers of Bizkaia, Basque Country (North of Iberian Peninsula), Bull. Fr. Pêche Piscic., 356, 17-30.

GAUDIOSO V.R., CELADA J.D., CARRAL J., RODRÍGUEZ, P.L., 1987. El cangrejo de río en León. Universidad de León, León (In Spanish).

GIL J.M., 1999. Situación, biología y conservación del cangrejo de río autóctono (Austropotamobius pallipes) en la provincia de Granada. Doctoral Dissertation. University of Granada. 211 p. (In Spanish).

GRANDJEAN F., FRELON-RAIMOND M., SOUTY-GROSSET C., 2002. Compilation of molecular data for the phylogeny of the genus Austropotamobius: one species or several? Bull. Fr. Pêche Piscic., 367, 663-670.

GRANDJEAN F., GOUIN N., SOUTY-GROSSET C., DIÉGUEZ-URIBEONDO J., 2001. Drastic bottlenecks in the endangered crayfish species Austropotamobius pallipes in Spain and implications for its colonization history. Heredity, 86, 431-438.

HABSBURGO-LORENA A. S., 1979. Present situation of exotic species of crayfish introduced to Spanish continental waters. Freshwater Crayfish, 4, 175-184.

HOLDICH D.M., DOMANIEWSKI J.C.J., 1995. Studies on a mixed population of the crayfish Austropotamobius pallipes and Pacifastacus leniusculus in England. Freshwater Crayfish, 10, 37-45.

HOLDICH D.M., READER J.P., ROGERS W.D., HARLIOGLU M., 1995. Interactions between three species of crayfish (Austropotamobius pallipes, Astacus leptodactylus and Pacifastacus leniusculus). Freshwater Crayfish, 10, 45-56.

HOLDICH D.M., ROGERS W.D., 1997. The white-clawed crayfish, Austropotamobius pallipes, in Great Britain and Ireland with particular reference to its conservation in Great Britain. Bull. Fr. Pêche Piscic., 347, 597-616.

IUCN (INTERNATIONAL UNION FOR CONSERVATION) 1996. In BAILLIE J. and GROOMBRIDGE B. (eds.) 1996 IUCN Red List of Threatened Animals. IUCN, Gland, Switzerland.

LOZANO J., MARTÍN J., 1988. Trabajos de investigación sobre acuicultura y gestión en la provincia de Cuenca. In JCCM y DIPUTACIÓN DE CUENCA (eds.) I Jornadas de Acuicultura en Castilla-La Mancha, Cuenca. 155-197 (In Spanish).

MMA (MINISTERIO DE MEDIO AMBIENTE), 2003. Orden MAM/1653/2003, de 10 de junio, por la que se incluye al cangrejo de río en el Catálogo Nacional de especies amenazadas y se reclasifica y excluye de dicho Catálogo, respectivamente, al milano real de las Islas Baleares y a la culebra viperina de estas mismas islas. Boletín Oficial del Estado, 149, 24098 (In Spanish)

PLATTS W.S., MEGAHAN W.F., MINSHALL, G.W., 1983. Methods for evaluating stream, riparian and biotic conditions. United States Department of Agriculture. Intermountain Forest and Range Experiment Station. General Technical Report INT-138. $70 \mathrm{p}$.

RALLO A., GARCÍA-ARBERAS L. 2002. Differences in abiotic water conditions between fluvial reaches and crayfish fauna in some rivers of the Iberian Peninsula. Aquatic Living Resources, 15, 119-128.

SALVIDIO S., MORI M., LATTES A., GALLI L., ARILLO A., 2002. The freshwater crayfish Austropotamobius pallipes (Lereboullet, 1858) in Liguria NW Italy: implications for management at a regional level. Bull. Fr. Pêche Piscic., 367, 663-670. 
SCHULZ R., STUCKI T., SOUTY-GROSSET C., 2002. Management: reintroductions and restocking. Bull. Fr. Pêche Piscic., 367, 917-922.

SIMMONSON T.D., LYONS J., KANEHL P.D., 1994. Guidelines for evaluating fish habitat in Wisconsin streams. United States Department of Agriculture. North Central Forest Experiment Station. General Technical Report NC-164. 36 p.

TEMIÑO C., SÁEZ-ROYUELA C., 1998. Resumen de los inventarios de cangrejo autóctono Austropotamobius pallipes realizados en la provincia de Burgos entre 1984 y 1997. Internal report of the Servicio Territorial de Medio Ambiente de Burgos (In Spanish).

TORRE M., RODRÍGUEZ P, 1964. El cangrejo de río en España. Servicio Nacional de Pesca Fluvial y caza. Ministerio de Agricultura, Madrid. 107 p. (In Spanish).

TROSCHEL H.J. 1997. Distribution and ecology of Austropotamobius pallipes in Germany. Bull. Fr. Pêche Piscic., 347, 639-648.

TROSCHEL H.J., DEHUS P., 1993. Distribution of crayfish species in the Federal Republic of Germany, with special reference to A. pallipes. Freshwater Crayfish, 9, 390-398. 